\title{
THEORETICAL MODEL OF ALDOLASE FRUCTOSE 1,6 BIPHOSPHATE FROM Trypanosome brucei
}

\author{
MARY I. CORDERO DE TROCONIS*1, TRINA COLMAN², MARGOT LEDEZMA DE RUIZ \\ ${ }^{*}{ }_{1,2}$ Molecular Modeling Lab., School of Pharmacy, Universidad Central de Venezuela. Ciudad Universitaria, Caracas1061 Venezuela \\ ${ }^{2}$ Biochemistry Lab, School of Pharmacy, Universidad Central de Venezuela
}

(Received: March 6, 2009 - Accepted: May 30, 2010)

\begin{abstract}
Parasites from the Trypanosomatidae family cause different illnesses in human and animals. Drugs currently in use against them have limited efficacy and high toxicity, therefore is very important that scientists continue their efforts to look for new targets for the treatment of these diseases. Trypanosome brucei is the causal agent of African trypanosomiasis (sleeping sickness) in human and animals, and is one of the trypanosome species that are actively investigated.

Trypanosomes in the blood depend entirely from the glycolisis in order to obtain energy, so this is one of the possible points of attack. The aldolase fructose biphosphate seems to be until now the regulator of the glycolisis so its study is very important. The modeled three-dimensional structure of aldolase fructose biphosphate from Trypanosome brucei was obtained using the program Modeller based on the sequence previously published by Clayton. This modeled structure will help as a starting point for future rational chemotherapy studies, and the methodology described could be used for other enzymes of unknown three dimensional structures.
\end{abstract}

Keywords: Trypanosome Brucei, Homology Modeling, MODELLER

\section{INTRODUCTION}

In the last years there have been great efforts in protein modeling. In this area one of the most important challenges is to predict the three-dimensional structure of a protein using only its aminoacid sequence with similar accuracy to the experimentally obtained in order to permit the generation of in silico protein models. This task is very important because the modeled structures could be used in other research works such as Rational Drug Design, possible protein functions analysis and antigenic behavior. Additionally the dramatic development about DNA sequences from the genome projects in the last years has added a lot of protein sequences of unknown tridimensional structure and functions. Only the National Center for Biotechnology Information, NCBI, contains in its database at least sequences for 700.000 non identical proteins ${ }^{1-5}$. Therefore in Silico modeling of proteins is a crucial task, especially for those in which the traditional techniques fail (for example if they are too big for an NMR analysis) or they can not be crystallized ${ }^{6}$.

One of the techniques used to develop in Silico Models is Homology Modeling that is based in two observations: the first one is that a protein structure is determined only by its aminoacid sequence, and the second that during evolution the structure is more stable and changes more slowly that the associated sequence, in such way similar sequences have a tendency to adopt almost identical three dimensional structures. These relationships were initially identified by Chotia and Lesk in $1986^{7}$.

Also it is known that related proteins tend to have similar molecular functions ${ }^{5}$ and the conserved residues are particularly strong in the catalytic sites and in the region involved in the binding to small molecules. ${ }^{8}$

MODELLER is a software for Homology Modeling that allows the construction of three dimensional structures of the modeled proteins using known related structures and calculates several models by satisfaction of spatial restraints that can be derived from different sources such as NMR experiments, electronic microscopy, mutagenesis, etc. ${ }^{9-12}$

MODELLER utilizes multiple alignments of protein sequences. This method is very useful to locate missing residues in the model and to include residues that are not present in the structures used as references. When the alignment is satisfactory Modeller calculates one or several models. Finally it uses the optimization module to refine the calculated three dimensional structures.

In this work we obtained a three dimensional structure of aldolase fructose 1-6 biphosphate from Trypanosome brucei, using as only data the sequence previously reported by Clayton ${ }^{13}$. This enzyme is a possible target to design new compounds active against trypanosomes, because it is involved in the parasite glycolitic process ${ }^{14}$. This glycolitic process is the only one able to generate ATP in the Trypanosome brucei form present in the sanguine flow. Therefore is important to have a theoretical model that could be used in future drug interaction studies, because it is a challenge to search for new drugs related to the treatment of trypanosomiasis ${ }^{15,16}$ since the drugs actually in use are of limited efficacy and can produce toxic effects and parasite resistance ${ }^{17,18}$

We used as reference models rabbit muscle aldolse ${ }^{19}$ and human aldolase $\mathrm{e}^{20}$ obtained from Brookhaven database ${ }^{21}$. Additionally efficacy of MODELLER has been evaluated for the development of three-dimensional structures starting from the aminoacid sequence of a protein. For this purpose it was used as validating enzyme a crystalline structure recently reported ${ }^{22}$ concluding that the software is very useful, especially for the modeling of the protein core.

\section{EXPERIMENTAL}

1. We look for similar structures to Trypanosome brucei aldolase in the Brookhaven Protein Database ${ }^{21}$ that could be used as reference structures and selected a rabbit aldolase ${ }^{19}$ and human aldolase ${ }^{20}$ identified as $1 \mathrm{ADO}$ and $1 \mathrm{ALD}$ in the database. (Figure 1)
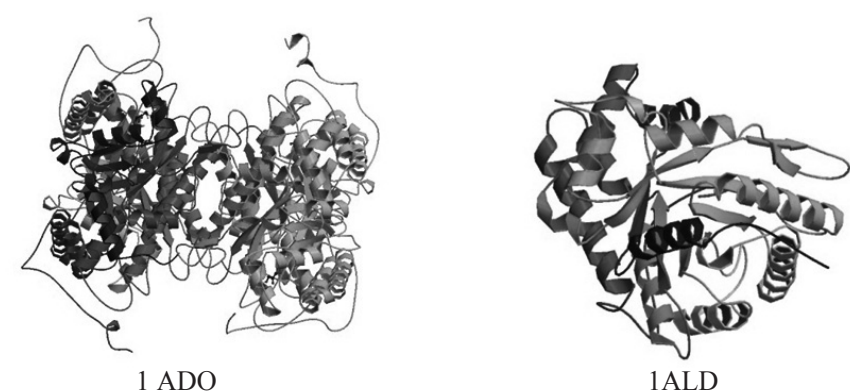

Figure 1. Three dimensional structures of rabbit aldolase $(1 \mathrm{ADO})^{19}$ and human aldolase $(1 \mathrm{ALD})^{20}$ used as reference structures.

2. Then the reference sequences were aligned with the Trypanosome brucei aldolase 1,6 biphosphate sequence previously reported by Clayton ${ }^{13}$ using the multiple alignments method and using the conserved regions as reference.

3. The calculation was run using MODELLER ${ }^{9-12}$, software property from Accelrys/Biosim. MODELLER uses the Charmm force field ${ }^{23}$.

4. There were generated five possible models and their corresponding tables for protein density violations (PDF Tables) for several properties for each model. The programs allows generation of 18 protein density violation types, between them bond distance, improper torsion, disulfur distances and non bonding interactions. The five generated models are shown in Figure 2.

5. The PDF violation tables were analyzed. A great PDF value indicates a poor model satisfaction of the spacial restrictions established from 
the reference structures. In the Table 1 it is shown the average PDF violations for each model. For each violation ribbon structures were also generated showing different wide in violation points, if the ribbon is wider the violation is greater. (Example in Figure 3).

\section{RESULTS AND DISCUSSION}

The five generated structures were identified as TRYPN 1 to 5. (Models shown in Figure 2). All of them have a beta barrel TIM structure characterized for an $\alpha / \beta$ folding. The barrel is formed by eight alpha helices. This structure is similar to the reference protein structures.

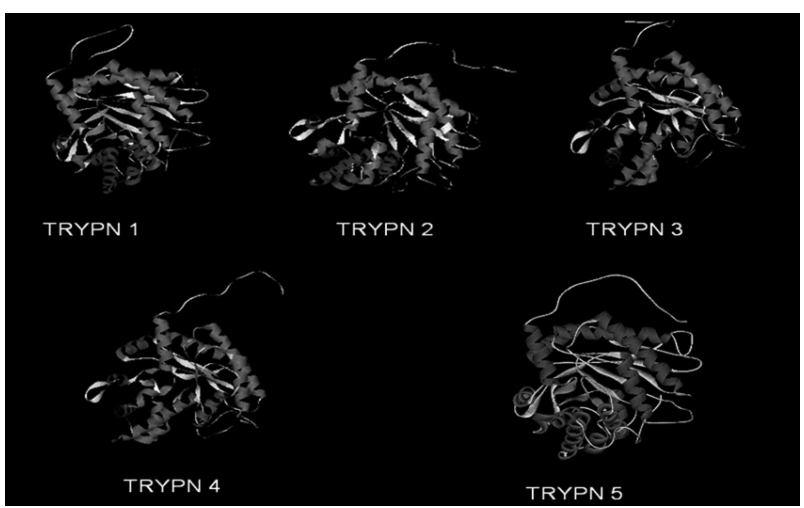

Figure 2. Theoretical models of aldolase fructose 1,6 biphosphate generated using MODELLER

After the PDF violations analysis of each model the TRYPN3 structure was selected as the more probable structure of the enzyme. It has the lower PDF violations value and the lower energy. (Values shown in Table 1).

Table 1. PDF average and energy values for models TRYPN1, TRYPN2, TRYPN3, TRYPN4 and TRYPN5.

\begin{tabular}{|l|l|l|l|}
\hline \hline MOL_TITUSG & A & B & C \\
\hline 1 & Molecule & Value & \\
\hline 2 & Spec1 & -Ln & \\
\hline 3 & $*$ & PDF & Energy \\
\hline 4 & TRYPN1 & 2529.2 & 1191.51 \\
\hline 5 & TRYPN2 & 2477.6 & 1204.06 \\
\hline 6 & TRYPN3 & 2276.3 & 1150.32 \\
\hline 7 & TRYPN4 & 2546.5 & 1219.09 \\
\hline 8 & TRYPN5 & 2603.3 & 1185.64 \\
\hline \hline
\end{tabular}

In addition to the PDF tables, the ribbon projections of the different models were observed in order to analyze the zones presenting the PDF violations. In Figure 3 examples are shown for different PDF violations that are zones in which the ribbon is wider.

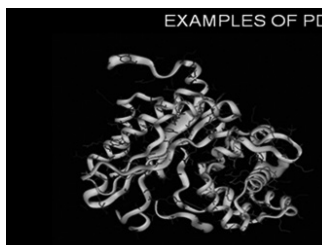

BOND ANGLE PDF VIOLATIONS

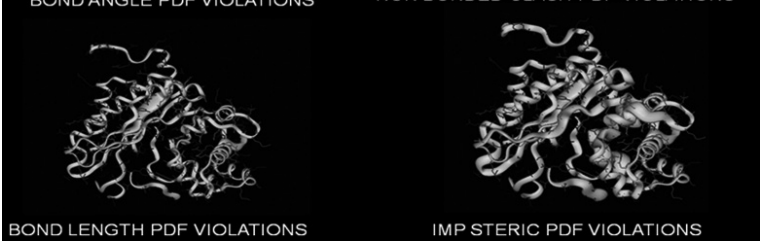

Figure 3. Graphical example of several PDF violations for model TRYPN3
The generated structure was superimposed with the three dimensional structures of the enzymes used as reference giving a good alignment, especially with the rabbit aldolase structure that presents a greater homology with the studied sequence of the crystalline structure of 1,6 aldolase biphosphate reported in the Brookhaven protein database identified as $1 \mathrm{~F} 2 \mathrm{~J}^{22}$. Models shown in Figure 4. We can conclude that TRPN3 complies with the structural requirements established in the program according to the reference structures.

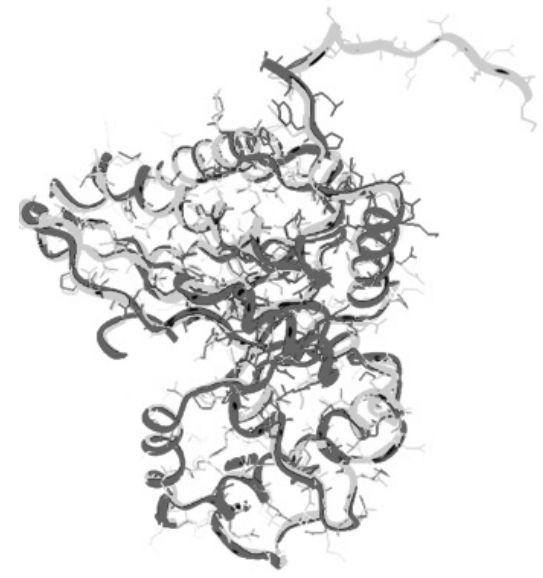

Figure 4. Superimposition of the human aldolase (in light gray) with Model TRYPN3 (in dark gray).

In order to validate our results, TRYPN3 was compared with the crystalline structure of Trypanosome brucei aldolase published by Chudzik et al, reported in the Brookhaven Database protein as $1 \mathrm{~F} 2 \mathrm{~J}^{22}$ and we obtained a very good correlation with the aldolase core. As expected, differences were observed in the $\mathrm{N}$ terminal loop because this part is not present in the structures used as reference.

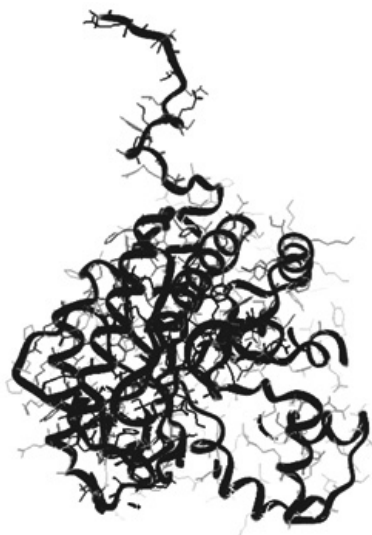

$1 \mathrm{~F} 2 \mathrm{~J}$

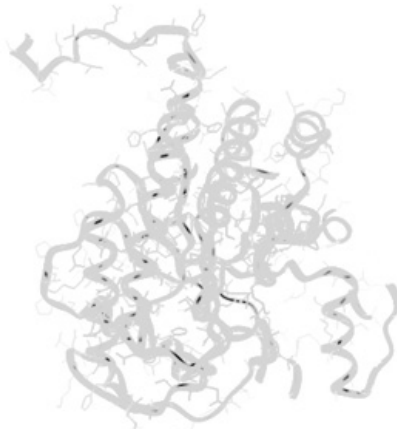

TRYPN3
Figure 5. Crystalline structure $1 \mathrm{~F} 2 \mathrm{~J}^{22}$ and theoretical model TRYPN3

\section{CONCLUSIONS}

Our Model TRYPN3 presents the same folding of the aldolase crystallized and reported by Chudzik et al, TIM barrel (beta/alpha) which is also the reported for other aldolases. The $\mathrm{C}$ terminal of our model finish with a Tyr residue that is catalytically important in all the reported aldolases. In the $\mathrm{N}$ terminal presents a flexible chain. Our model also presents the conserved amino acids for the active site in similar position to the crystalline structure 1F2J. From our results we can conclude that we obtain an acceptable model for the enzyme and that MODELLER is a good option for homology modeling beginning only with the aminoacid sequence of a protein, especially for the protein core. 


\section{REFERENCES}

1.- J.C. Venter, M.D. Adams, E.W. Myers, P.W. Li, R.J. Mural, G.G. Sutton, H.O. Smith, M. Yandell, C.A. Evans, R.A. Holt, J.D. Gocayne, P. Amanatides, R.M. Ballew, D.H. Huson, J.R. Wortman, Q. Zhang, C.D Kodira, X.H. Zheng, L. Chen, M. Skupski, G. Subramanian, P.D. Thomas, J. Zhang, G.L. Gabor Miklos, C. Nelson, S. Broder, A.G. Clark, J. Nadeau, V.A. McKusick, N. Zinder, A.J. Levine, R.J Roberts, M. Simon, C. Slayman, M. Hunkapiller, R. Bolanos, A. Delcher, I. Dew, D. Fasulo, M. Flanigan, L. Florea, A. Halpern, S. Hannenhalli, S. Kravitz, S. Levy, C. Mobarry, K. Reinert, K. Remington, J. Abu-Threideh, E. Beasley, K. Biddick, V. Bonazzi, R. Brandon, M. Cargill, I. Chandramouliswaran, R. Charlab, K. Chaturvedi, Z. Deng, V. Di Francesco, P. Dunn, K. Eilbeck, C. Evangelista, A.E. Gabrielian, W. Gan, W. Ge, F. Gong, Z. Gu, P. Guan, T.J. Heiman, M.E. Higgins, R.R. Ji, Z. Ke, K.A. Ketchum, Z. Lai, Y. Lei, Z. Li, J. Li, Y. Liang, X. Lin, F. Lu, G.V. Merkulov, N. Milshina, H.M. Moore, A.K. Naik, V.A. Narayan, B. Neelam, D. Nusskern, D.B. Rusch, S. Salzberg, W. Shao, B. Shue, J. Sun, Z. Wang, A. Wang, X. Wang, J. Wang, M. Wei, R. Wides, C. Xiao, C. Yan, A. Yao, J. Ye, M. Zhan, W. Zhang, H. Zhang, Q. Zhao, L. Zheng, F. Zhong, W. Zhong, S. Zhu, S. Zhao, D. Gilbert, S. Baumhueter, G. Spier, C. Carter, A. Cravchik, T. Woodage, F. Ali, H. An, A. Awe, D. Baldwin, H. Baden, M. Barnstead, I. Barrow, K. Beeson, D. Busam, A. Carver, A. Center, M.L. Cheng, L. Curry, S. Danaher, L. Davenport, R. Desilets, S. Dietz, K. Dodson, L. Doup, S. Ferriera, N. Garg, A. Gluecksmann, B. Hart, J. Haynes, C. Haynes, C. Heiner, S. Hladun, D. Hostin, J. Houck, T. Howland, C. Ibegwam, J. Johnson, F. Kalush, L. Kline, S .Koduru, A. Love, F. Mann, D. May, S. McCawley, T. McIntosh, I. McMullen, M. Moy, L. Moy, B. Murphy, K. Nelson, C. Pfannkoch, E. Pratts, V. Puri, H. Qureshi, M. Reardon, R. Rodriguez, Y.H. Rogers, D. Romblad, B. Ruhfel, R. Scott, C. Sitter, M. Smallwood, E. Stewart, R. Strong, E. Suh, R. Thomas, N.N. Tint, S. Tse, C. Vech, G. Wang, J. Wetter, S. Williams, M. Williams, S. Windsor, E. Winn-Deen, K. Wolfe, J. Zaveri, K. Zaveri, J.F. Abril, R. Guigó, M.J. Campbell, K.V. Sjolander, B. Karlak, A .Kejariwal, H. Mi, B. Lazareva, T. Hatton, A. Narechania, K. Diemer, A. Muruganujan, N. Guo, S. Sato, V. Bafna, S. Istrail, R. Lippert, R. Schwartz, B. Walenz, S. Yooseph, D. Allen, A. Basu, J. Baxendale, L. Blick, M. Caminha, J. Carnes-Stine, P. Caulk, Y.H. Chiang, M. Coyne, C. Dahlke, A. Mays, M. Dombroski, M. Donnelly, D. Ely, S. Esparham, C. Fosler, H. Gire, S. Glanowski, K Glasser, A. Glodek, M. Gorokhov, K. Graham, B. Gropman, M. Harris, J. Heil, S. Henderson, J. Hoover, D. Jennings, C. Jordan, J. Jordan, J. Kasha, L. Kagan, C. Kraft, A. Levitsky, M. Lewis, X. Liu, J. Lopez, D. Ma, W. Majoros, J. McDaniel, S. Murphy, M. Newman, T. Nguyen, N. Nguyen, M. Nodell, S. Pan, J. Peck, M. Peterson, W. Rowe, R. Sanders, J. Scott, M. Simpson, T. Smith, A. Sprague, T. Stockwell, R. Turner, E. Venter, M. Wang, M. Wen, D. Wu, M. Wu, A. Xia, A. Zandieh, X .Zhu., Science, 291, 1304,(2001)

2.- E.S. Lander, L.M. Linton, B. Birren, C. Nusbaum, M.C. Zody, J. Baldwin, K. Devon, K. Dewar, M. Doyle, W. FitzHugh, R. Funke, D. Gage, K.,Harris, A. Heaford, J. Howland, L. Kann, J. Lehoczky, R. LeVine, P. McEwan, K. McKernan, J. Meldrim, J.P. Mesirov, C. Miranda, W. Morris, J. Naylor, C. Raymond, M. Rosetti, R. Santos, A. Sheridan, C. Sougnez, N. Stange-Thomann, N. Stojanovic, A. Subramanian, D. Wyman, J. Rogers, J. Sulston, R. Ainscough, S. Beck, D. Bentley, J. Burton, C. Clee, N. Carter, A. Coulson, R. Deadman, P. Deloukas, A. Dunham, I. Dunham, R. Durbin, L. French, D. Grafham, S. Gregory, T. Hubbard, S. Humphray, A. Hunt, M. Jones, C. Lloyd, A. McMurray, L. Matthews, S. Mercer, S. Milne, J.C. Mullikin, A. Mungall, R. Plumb, M. Ross, R. Shownkeen, S. Sims, R.H. Waterston, R.K. Wilson, L.W. Hillier, J.D. McPherson, M.A. Marra, E.R. Mardis, L.A. Fulton, A.T. Chinwalla, K.H. Pepin, W.R. Gish, S.L. Chissoe, M.C. Wendl, K.D. Delehaunty, T.L. Miner, A. Delehaunty, J.B. Kramer, L.L. Cook, R.S. Fulton, D.L. Johnson, P.J. Minx, S.W. Clifton, T. Hawkins, E. Branscomb, P. Predki, P. Richardson, S. Wenning, T. Slezak, N. Doggett, J.F. Cheng, A. Olsen, S. Lucas, C. Elkin, E. Uberbacher, M. Frazier, R.A. Gibbs, D.M. Muzny, S.E. Scherer, J.B. Bouck, E.J. Sodergren, K.C. Worley, C.M. Rives, J.H Gorrell, M.L. Mektzker, S.L. Naylor, R.S. Kucherlapati, D.L. Nelson, G.M. Weinstock, Y. Sakaki, A. Fujiyama, M. Hattori, T. Yada, A. Toyoda, T. Itoh, C. Kawagoe, H. Watanabe, Y. Totoki, T. Taylor, J. Weissenbach, R. Heilig, W. Saurin, F. Artiguenave, P. Brottier, T. Bruls, E. Pelletier, C. Robert, P. Wincker, D.R. Smith, L. Doucette-Stamm, M. Rubenfield, K. Weinstock, H.M. Lee, J. Dubois, A. Rosenthal, M. Platzer, G. Nyakatura, S. Taudien, A. Rump, H. Yang, J. Yu, J. Wang, G. Huang, J. Gu, L.
Hood, L. Rowen, A. Madan, S. Qin, R.W. Davis, N.A. Federspiel, A.P. Abola, M.J. Proctor, R.M. Myers, J. Schmutz, M. Dickson, J. Grimwood, D.R. Cox, M.V. Olson, R. Kaul, C. Raymond, N. Shimizu, K. Kawasaki, S. Minoshima, G.A. Evans, M. Athanasiou, R. Schultz, B.A. Roe, F. Chen, H. Pan, J. Ramser, H. Lehrach, R. Reinhardt, W.R. McCombie, M. de la Bastide, N. Dedhia, H. Blöcker, K. Hornischer, G. Nordsiek, R. Agarwala, L. Aravind, J.A. Bailey, A. Bateman, S. Batzoglou, E. Birney, P. Bork, D.G. Brown, C.B. Burge, L. Cerutti, H.C. Chen, D. Church, M. Clamp, R.R. Copley, T. Doerks, S.R. Eddy, E.E. Eichler, T.S. Furey, J. Galagan, J.G. Gilbert, C. Harmon, Y. Hayashizaki, D. Haussler, H. Hermjakob, K. Hokamp, W. Jang, L.S. Johnson, T.A. Jones, S. Kasif, A. Kaspryzk, S. Kennedy, W.J. Kent, P. Kitts, E.V. Koonin, I. Korf, D. Kulp, D. Lancet, T.M. Lowe, A. McLysaght, T. Mikkelsen, J.V. Moran, N. Mulder, V.J. Pollara, C.P. Ponting, G. Schuler, J. Schultz, G. Slater, A.F. Smit, E. Stupka, J. Szustakowski, D. Thierry-Mieg, J. Thierry-Mieg, L. Wagner, J. Wallis, R. Wheeler, A. Williams, Y.I. Wolf, K.H. Wolfe, S.P. Yang, R.F. Yeh, F. Collins, M.S. Guyer, J. Peterson, A. Felsenfeld, K.A. Wetterstrand, A. Patrinos, M.J. Morgan, P. de Jong, J.J. Catanese, K. Osoegawa, H. Shizuya, S. Choi, Y.J. Chen; International Human Genome Sequencing Consortium, Nature, 409:860, (2001)

3.- $\quad$ R. Maleszka, H.G. de Couet, G.L. Miklos., Proc. Natl. Acad. Sci. U. S. A., 95:3731, (1998)

4.- $\quad$ G.L. Miklos, R. Maleszka, Proteomics. 1(2):169, (2001)

5.- S. Henikoff, E.A. Greene, S. Pietrokovski, P. Bork, T.K. Attwood, L. Hood, Science.,278(5338):609, (1997)

6.- E. Krieger, S. B. Nabuurs, G. Vriend , Methods Biochem Anal.;44:509,(2003)

7.- $\quad$ C. Chothia, A.M. Lesk., EMBO J. 5(4):823, (1986)

8.- A.E. Todd, C.A. Orengo, J.M. Thornton, Curr. Opin. Struct. Biol., 3:548, (1999)

9.- S.Sali, Modeller, "Implementing 3D protein modelling en $\mathbf{m c}^{2}$, volumen 2, pag 5, Molecular Simmulations Inc., Burlington, MA, (1995)

10.- N. Eswar, M. A. Marti-Renom, B. Webb, M. S. Madhusudhan, D. Eramian, M. Shen, U. Pieper, A. Sali. Comparative Protein Structure Modeling With MODELLER. Current Protocols in Bioinformatics, John Wiley \& Sons, Inc., Supplement 15, 5.6.1-5.6.30, 200.

11.- M.A. Marti-Renom, A. Stuart, A. Fiser, R. Sánchez, F. Melo, A. Sali, Annu. Rev. Biophys. Biomol. Struct. 29, 291, (2000).

12.- A. Sali \& T.L. Blundell, J. Mol. Biol. 234, 779 (1993)

13.- C. Clayton, EMBO J., 4, 2997,(1985)

14.- C.L. Verlinde, V. Hannaert, C. Blonski, M .Wilson, J.J Perie., L.A Fothergill-Gilmore., F.R Opperdoes., M.H Gelb., W.G. Hot , P. Michels, Drug. Resist.Updates, $\mathbf{4 , 5 0 ( 2 0 0 1 )}$

15.- G.C. Muscia, M. Bollini, A.M. Bruno and S.E Asis, J. Chil. Chem. Soc. [online], 51, 859, (2006)

16.- C.A.Carollo, A.R.Hellmannn-Carollo, J.M. de Siqueira, S. Albuquerque, . J. Chil. Chem. Soc. [online], 51,837, (2006)

17.- R. E. Howells, Parasitology, 90, 687 (1985)

18.- A. Lüscher, H.P. de Koning, P. Mäser, Curr Pharm Des.;13(6):555 (2007)

19.- N. Blom, J. Sygusch, Nat. Struct.Biol. ,4,36 (1997)

20.- S.J. Gamblin, G.J. Davies, J.M. Grimes, R.M. Jackson, J.A Littlechild, H.C. Watson, J.Mol.Biol, 219,573 (1991)

21.- H.M. Berman, J. Westbrook, Z. Feng, G. Gilliland, T.N. Bhat, H. Weissig, I.N. Shindyalov, P.E. Bourne, Nuclei Acids Res., 28, 235 (2000)

22.- D.M Chudzik,. P.A Michels,., S. de Walque, W.G. Hol, J.Mol.Biol. 300: 697(2000)

23.- B.R. Brooks, R.E. Bruccoleri, B.D. Olafson, D.J. States, S. Swaminathan, M. Karplus , J Comp Chem 4: 187, (1983)

\section{ACKNOWLEDGEMENTS}

To the Consejo de Desarrollo Cientifico y Humanistico de la Universidad Central de Venezuela, projects CDCH-06.30.3440.95, 06-10-4296-98 and CDCH 06.06.6996.2007 